\title{
Ontogenetic structure of coenopopulations and variability of morphoparameters of Iris reticulata M. Bieb.
}

Nigar Mursal ${ }^{1}$

Naiba P. Mehdiyeva

Institute of Botany, Azerbaijan National Academy of Sciences, Badamdar 40, Baku, AZ1004, Azerbaijan

Abstract: Ontogenetic and demographic structure of coenopopulations $(\mathrm{CP})$ of the rare species Iris reticulata M.Bieb. in Quba region of Azerbaijan is described in this article. It has been revealed that all coenopopulations are left-sided, the highest percentage in CP1 and $\mathrm{CP} 2$ are generative individuals, in $\mathrm{CP} 3$ pregenerative individuals. According to the value of delta $(\Delta)$ and omega $(\omega)$ all 3 coenopopulations are "young" type. Morphometric analysis of individuals in coenopopulation and correlation analysis between morphometric parameters was performed and have been investigated the effects of climate factors to their variability and plastics. The difference in the number of rainy and frosty days, as well as in temperature degrees for 2 years has affected their morphometric features, variability and plasticity. It has been determined that the highest value between morphoparameters in $\mathrm{CP} 2$ are length of leaf, width of leaf, length of flower shoot, length of petal, length of root, number of roots but in CP3 width of petal, length of bulb, width of bulb. The lowest morphological measurements were observed in CP1. The variation coefficients showed that in all three coenopopulations the least varied is length of root $(10-12 \%)$ and high varied of length of flower shoot (33-35\%). In all coenopopulations, the most plastic morphoparameter is length of flower shoot (0.6-0.62), in addition to CP2 and CP3 -width of leaf $(0.67-0.72)$. The least plastic is length of root $(0.25-0.28)$ for all CP. The result of correlation analysis showed that the strong correlation between the parameters in all three coenopopulations is the length of flower shoot $\sim$ length of bulb. Investigations showed that anthropogenic and natural factors affect the decreasing the number of I. reticulata in the study area.

Key Words: ontogenetic structure, variability, plasticity, correlation, climate factor

Accepted for publication: 5 December 2018

E-mail: nigarbiology1292@mail.ru

\section{INTRODUCTION}

One of the important and urgent tasks of modern botany is the protection of rare species. A significant reduction in habitat, the loss of any population and especially the extinction of the species is the irretrievable loss of unique genetic information and causes irreparable damage to biodiversity in general. In the study of rare plant species, the using of morphometric methods is one of the main methods for obtaining a representative amount of data on plant individuals, the status of specific populations growing in different environmental conditions and under different degrees of anthropogenic impact [Rabotnov, 1975; Uranov, 1977].

The genus Iris L. (family Iridaceae Juss.) includes more than 200 species distributed mostly in the northern part of the world [Alekseyeva, 2008]. According to the flora of Caucasus [Flora Kavkaza, 1940] this genus is represented by 30, in Flora of Azerbaijan [Flora Azerbaidjana, 1952] 26 and in "Conspect of the flora of Caucasus" [Konspekt Flori Kavkaza, 2006] by 37 species.

Various species of the genus Iris have been researched the coenopopulations in different areas. E. Khomann et al. [2016] conducted a monitoring of the coenopopulation of the species I. aphylla L. in Bryansk region during 2010-2015 and determined that the coenopopulations of this species commonly in xeromezophyte broad-leaved forests. M. Senchukova et al. [2017] and A. Khapuqin et al. [2015] were investigated the populations of the species I. aphylla in the territory of the National Park of the Republic of Mordovia and they were found that the type of population is vegetativeoriented. A. Shmareva et al. [2014] were studied two coenopopulations I. notha M.Bieb. in Azov district of Rostov region and revealed that the both coenopopulations are mature type and well propagate by seed. V. Mu-Za-Chin and V. Shukal [2016] have studied 6 coenopopulations of the rare species I. sibirica L. in Bryansk region and it has been established that growth by seed is weak, vegetative reproduction prevails in these coenopopulations.

V. Sericova and her colleagues [2013] studied the ontogenetic structure of the species I. pumila L. and found that individuals were vegetated during the summer and their above ground surface was dried up by mid-September. The transition of the seedlings to the juvenile 
stage is often delayed and reaches to the immature age in the second year, in the third year-the virgin phase begins and they remain at that stage for 2 years. The plant grows to the generative stage in 5 th year and takes on the structure of the last vital form of the species.

Isoflavanoids [Morita et al., 1972; Wu, Xu, 1992], xinons [Seki et al., 1994] and triterpenoids [Krick et al., 1983] were found in species belonging to the genus Iris. Ch. Williams [1997] proved that there are 17 glycosylphlavons in this genus. J. Harborne, C. Williams [2000] also note that the second metabolites are rich in Iridaceae family. Isoflavones were discovered firstly in I. florentina L., then in I. pseudopumila Tineo. Generally, in all Iris plants have different flavonoids [Rastitelnye resursy, 2014].

Some of Iris species includes medicinal herbs. One of these species is I. pseudocorus L. This species is officinal medicinal plant, is widely used in folk medicine, homeopathy and experimental studies in the disease of gastroenterostomy, urinary, epilepsy, diabetes, acute respiratory infections [Rastitelniye resursi, 1994]. Precious biologically active substances of the underground part have viral, inflammatory and antibacterial properties [Alekseyeva, 2008]. I. musulmanica Fomin is used in the treatment of trichophytics (fungal disease of skin) in Indian medicine and scrophylaxis in folk medicine. In I. pumila has been found substance which characterized by detoxication (rabies) in folk medicine and antifungal activity in experimental studies [Rastitelniye resursi, 1994]. The majority of Iris species are used as decorative, as food (I. reticulata), as fodder for horse, camel, sheep (I. biglumis Vahl s.1., I. ensata Thunb., I. pumila, I. ruthenica Ker-Gawl., I. setosa Pall.ex Link, I. sibirica), as dye (I. alberti Regel, I. setosa), as aromatic (I. imbricata Lindl.) and as honey resource (I. pseudacorus, I. pumila, I. ruthenica) [Rastitelniye resursi, 1994].

A wide range of using of Iris species leads to a significant reduction in their natural habitats. Thus, 17 species of Iris are included in the Red Book of Azerbaijan [2013] (I. acutiloba C.A. Mey, I. annae Grossh., I. camillae Grossh., etc.). One of them is I. reticulata with category NT - "Being in a state close to threatening." This species has not been studied in terms of studying ontogenetic features, the structure of coenopopulations and morphometric changes. The aim of the research is studying the ontogenetic properties, status of coenopopulation (CP), variability of morphological features and plasticity of I. reticulata in Quba region and determining correlations between morphoparameters.

\section{MATERIAL AND METHODS}

Description of investigated object. I. reticulata - is a perennial herb with 10-20 (30) $\mathrm{cm}$ height. The bulb is ovoid, 1.5-2.5 cm wide, outside is dressed with brown mesh-fibrous sheaths, with rope roots. Leaves 2-4 green, thin, tetrahedral with whitish tip. Flower one or two, apical, on the short flower shoot. Perianth funnel, purple. The box is cylindrical, tapered to both ends. Flowering and fruiting in March-April. Cryptophyte-geophyte. It is distributed from the lowland to the middle mountain zone in 7 botanical and geographical regions of Azerbaijan (Quba part of the Greater Caucasus, Samur-Devechi lowlands, Kur-Araz lowlands, Kur plain, Qobustan and Diabar). Distributed on the edges of forest, on grassy slopes, sown fields and in bushes [Flora Azerbaidjana, 1952]. The study was conducted in March-April, 2017-2018 in the districts Gedik, Uchkun-Kupchal, Isnov of Quba region (Fig.1).

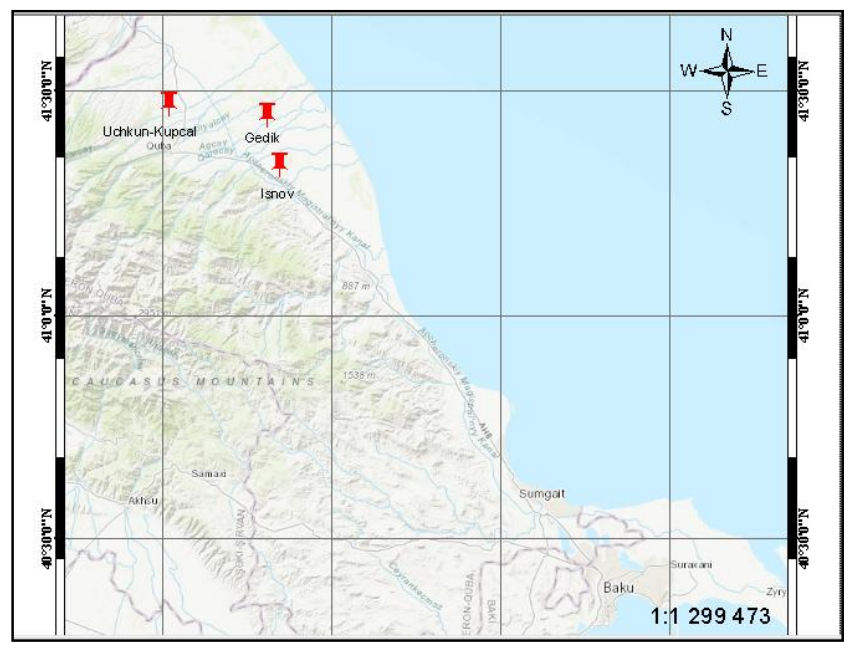

Figure 1. The routes of research

Description of investigation area. Mild-warm climate and cold dry winter weather types with precipitation are equally distributed in Quba. The territory of the district is located between the altitudes of $200-4500 \mathrm{~m}$ above sea level, so the climatic indicates very depending on the altitude. The average annual temperature of the air varies between $0-10^{\circ} \mathrm{C}$, in January to $-2-14^{\circ} \mathrm{C}$, and in July $5-23^{\circ} \mathrm{C}$. The maximum air temperature increases to $30-40^{\circ} \mathrm{C}$ degrees, the minimum temperature decreases to $-30^{\circ} \mathrm{C}$ in the cold months of the year. The average annual temperature on the surface of the soil varies from 12 degrees in the mountain ranges and ranges from $-2^{\circ} \mathrm{C}$ to $+27^{\circ} \mathrm{C}$ per year. Average annual amount of precipitation varies from 500 to $1500 \mathrm{~mm}$. The rain falls mainly in the autumn. The possible evaporation from the surface cover is 300-700 mm [Osədov et al., 2008]. 
Methods of research. The description of vegetation and phytocenoses was carried out according to the generally accepted methods in geobotany [Polevaya goebotanika, 1964]. In studying the ontogenetic and demographic structure of the coenopopulation, the principles and methods adopted by T. Rabotnov, A. Uranov and their followers [Uranov, 1975; Zauqolnova et al., 1988].

Ontogenetic (age) spectrum was studied as the main demographic parameters of the coenopopulation. To study the abundance and ontogenetic structure of $I$. reticulata CPs 7-8 small transects $\left(1 \mathrm{~m}^{2}\right)$ were laid in general model areas $\left(10 \mathrm{~m}^{2}\right)$. To determine the ontogenetic spectrum at these sites, the total number of individuals and the number of individuals of different age groups were calculated. The type of CP was determined by the delta-omega $(\Delta-\omega)$ classification of normal population of A. Uranov [1975] (Equation 1) and L.A. Zhivotovsky [2001] (Equation 2).

$$
\Delta=\sum \frac{k_{i} \cdot n_{i}}{N}
$$

Equation 1. $k_{\mathrm{i}}$ - «value» of $i$ ontogenetic status; $n-$ number of individuals of $i$ of ontogenetic structure in populations; $N$ - total number of individuals in population.

$$
\omega=\frac{\sum n_{i} \cdot e_{i}}{n_{i}}
$$

Equation 2. $n_{i}$ - absolute number of plants of $i$ - age state; $e_{i}$ - efficiency of plants of $i$ - ontogenetic status. in populations; $N$ - total number of individuals in population.

Morphometric analysis of individuals of $I$. reticulata was conducted according to Y. Zlobin [Zlobin et al., 2013]. Morphometric analysis was conducted on 30 randomly selected generative individuals by 9 parameters (length of leaf, width of leaf, length of flower shoot, length of petal, width of petal, length of bulb, width of bulb, length of root, number of roots). The mean value, standard deviation and variation coefficient $(\mathrm{CV})$ of the parameters were calculated.

To evaluate the amplitude of variability was used the experimental scale of S. Mamaev [1972], which consist of 6 levels: 1) $\mathrm{CV}<7 \%$ very weak; 2) $\mathrm{CV}=$ $8-12 \%$ weak; 3) $\mathrm{CV}=13-20 \%$ medium; 4) $\mathrm{CV}=21-$ $30 \%$ above; 5) $\mathrm{CV}=31-40 \%$ high; 6) $\mathrm{CV}>40 \%$ very high. Revealing the phytocenotic plasticity index (Ip)
(Equation 3) of morphological parameters was used the method of Y. Zlobin [1989a].

The method of Y. Odum [1952] was used to estimate the characteristics of individuals in the population (Equation 4).

$$
\mathrm{Ip}=(\mathrm{A}-\mathrm{B}) / \mathrm{A}
$$

Equation 3. A - maximum value of the parameter; $\mathrm{B}$ - minimum value of the parameter.in populations; $\mathrm{N}$ - total number of individuals in population.

$$
\operatorname{Iod}=\frac{\sigma 2}{\mathrm{x}}
$$

Equation 4. $\sigma$-dispersion; x-mean.

The correlation analysis [Rostova, 2002] was performed among the parameters: the length of leaf $\sim$ the width of the leaf, the length of bulb $\sim$ the width of bulb, the length of root $\sim$ number of roots, the length of petal $\sim$ the width of petal, the length of leaf $\sim$ the length of petal, the width of leaf $\sim$ the width of petal, the length of flower shoot $\sim$ the length of petal, the length of flower shoot $\sim$ width of petal. The coefficient of correlation (r) is divided into 4 groups according to the degree of relation: 1) $\mathrm{r}>0.8$ very strong; 2) $\mathrm{r}=0.71-0.8$ strong; 3 ) $\mathrm{r}=0.61-0.7$ medium; 4) $\mathrm{r}=0.5-0.6$ weak connection. Climate factor. According to the weather forecast presented by the Ministry of Ecology and Natural Resources of Azerbaijan Republic [http://eco.gov.az/az] for the year 2016 and 2017 average monthly temperature and the amount of rainy and frosty days for Quba region is calculated (Fig. 2). The average temperature for 2016 is $12.6^{\circ} \mathrm{C}$ and for $201713.1^{\circ} \mathrm{C}$. There was a sharp difference in the amount of frosty and rainy days, as the number of frosty days were 75 and the number of rainy days 245 in 2016, in 2017 respectively, 61 and 175 days.

The Latin names of the plants which found in vari-

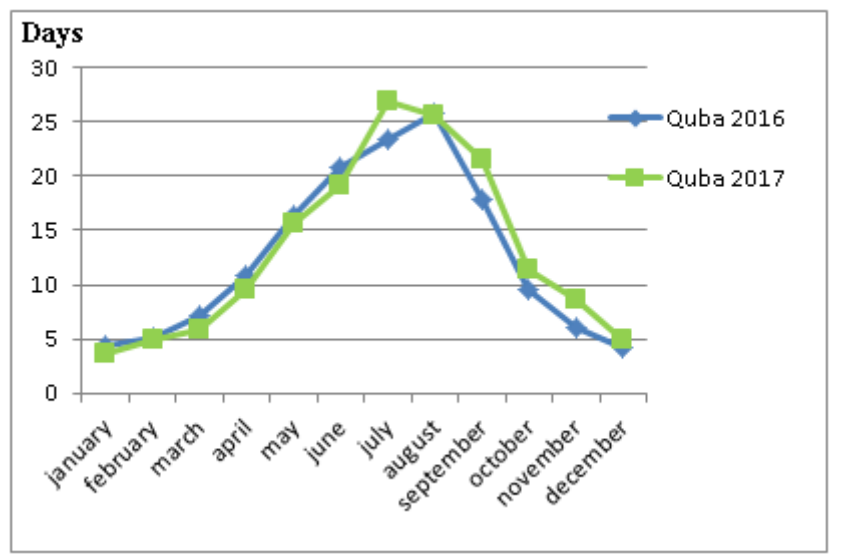




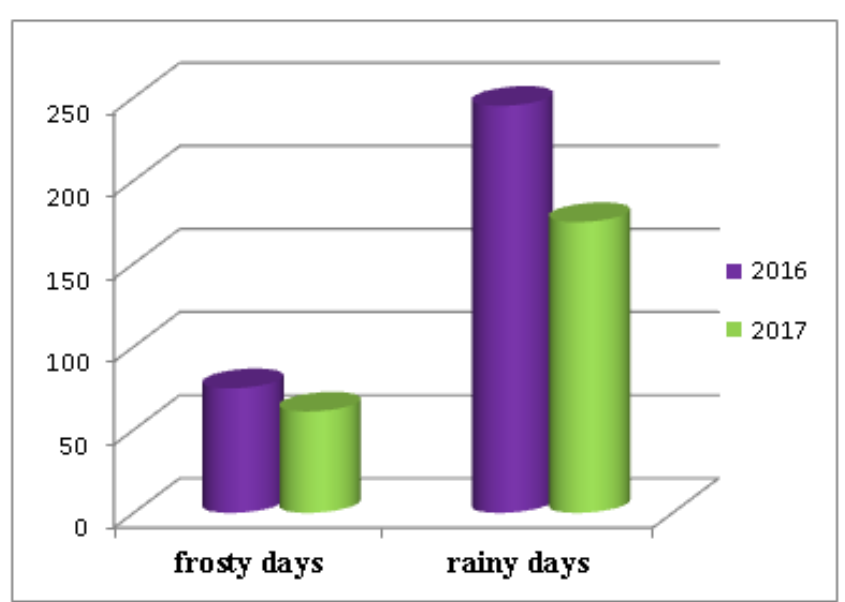

Figure 2. Average monthly temperature, the amount of rainy and frosty days for Quba region in populations; $\mathrm{N}$ - total number of individuals in population.

ous coenosis with $I$. reticulata, have been determined according to "Flora of Azerbaijan" [Flora Azerbaidjana, 1952], "Conspect of the Caucasus flora" [Konspekt Flori Kavkaza, 2006] and The Plant list [http://www. theplantlist.org]. The abundance of plants in the coenopopulation was based on the Braun-Blanquet Scale [Braun-Blanquet, Pavillard, 1925]. All statistical analyses were carried out in programs Microsoft Excel 2010 and GraphPad Prism 7.

\section{RESULTS AND DISCUSSION}

Phytocoenotic characteristic of habitat. CP1 was studied (2017) on grassy slopes in the district Gedik at a height of $248 \mathrm{~m}$ above sea level. The soil is brown and dry. In phytocoenosis distribute with $I$. reticulata from shrubs Paliurus spina-christi Mill (mark of abundance 1 point) and Crataegus curvicepala Lindm. (2 points), from herbaceous plants Orchis picta Raf. (1- 2 points), Veronica serpyllifolia L. (1 point), Capsella bursapastoris (L.) Medik. (3 points), Geranium albanum M. Bieb. (2 points), Silybum marianum (L.) Gaertn. (3 points) and others, as well as rare species - Pyrus salicifolia Pall., Tulipa biebersteinii Schult. et. Schult., Rhus coriaria L. The characteristics of the distribution of individuals in the coenopulation is contagious type ( $\operatorname{Iod}=1.56)$.

CP2 is investigated (2018) in the forests of the district Uchkun and Kupchal at a height of 704 above sea level. The soil is small-stony, dry. Forest is open and light. The height of leaf fall in the study area is 5-6 $\mathrm{cm}$. Carpinus caucasica L. here forms the forest formation Carpinuseta. In this forest are found together with the edificator from trees and shrubs Quercus crispata
Stev., Cornus mas L., Crataegus pentagyna Waldst. \& Kit. ex Willd. and Rosa tomentosa Sm. (2-3 points). In the herbaceous stage grow together Primula woronowii Losinsk, Viola arvensis Murray (3-4 points), Corydais marschalliana (Pall.) Pers., C. caucasica DC., Arum elongatum Stev. (2-3 points) with I. reticulata. The characteristics of the distribution of individuals in the coenopulation equal type ( $\operatorname{Iod}=0.4)$.

CP3 (2017) has been researched in bushes on the grassy slopes in Isnov village. The soil is brown, dry. In this coenosis take part with $I$. reticulata from the trees Cornus mas (2 points), from shrubs Rubus dolichocarpus Juz. (1-2 points), R. caesius L. (3 points), Crataegus curvisepala (2 points), Rhus coriaria (2-3 points), Cydonia oblonga Mill. (1-2 points), from herbs Daucus carota L. (2-3 points), Cichorium intybus L. (2 points), Teucrium polium L. (1-2 points), Primula woronowii Losinsk (2-3 points) and etc. The characteristics of the distribution of individuals in the coenopulation is contagious type (Iod $=1.68$ ). Our observations show that decreasing the number of $I$. reticulata in the study area is influenced by anthropogenic factors (collection for bulbs and decorative properties), natural (land slide, cattle grazing) factors. The self restoration process is late because of the weakening seed propagation.

Ontogenetic states. As the results of investigations it is found out that in 3 coenopopulations, relatively the number of juvenile individuals are (j) 12,$5 ; 110$, immature (im) $17 ; 8 ; 98$, virgin (v) 29; 9;68, young generative (g1) $37 ; 15 ; 56$, mature generative (g2) $20 ; 7 ; 64$; old generative (g3) 14; 3; 44, subenil (ss) 7; 1; 7. Senile individual (s) are not registered (Fig. 3, 4). As a result of studying the ontogenetic structure of coenopopulations of $I$. reticulata was established that all three coenopopulations are normal, but not completely (absence of senile individuals) and left-sided.

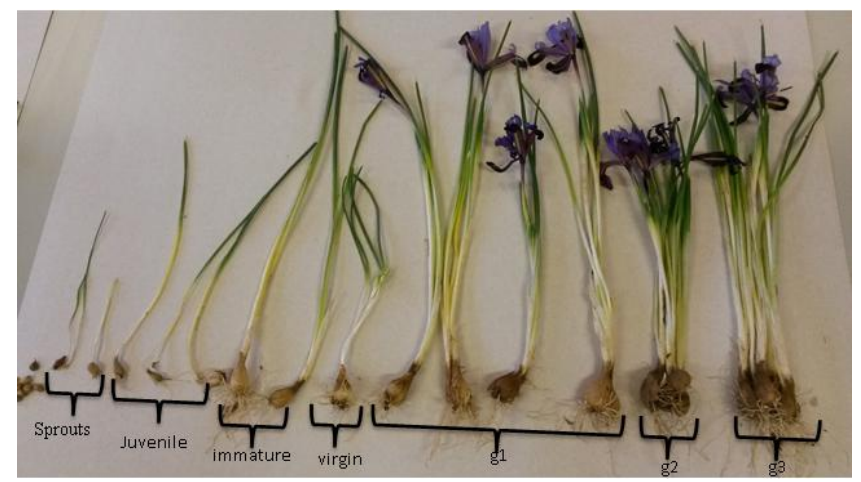

Figure 3. Individuals of I. reticulata in different ontogenetic states. 


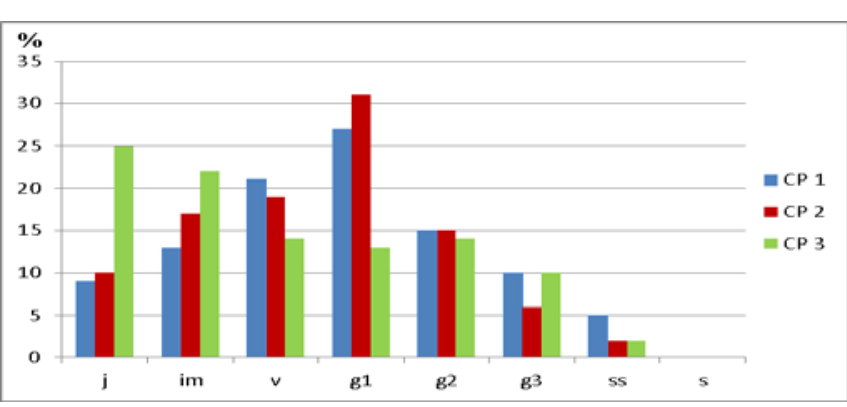

Figure 4. Ontogenetic structure of a rare species $I$. reticulata.

Studies have shown that in CP1 pregenerative individuals $43 \%$, generative individuals $52 \%$, and postgenerative individuals $5 \%$. There was no significant difference in $\mathrm{CP} 2$ and respectively $46 \%, 52 \%, 2 \%$. But, in $\mathrm{CP} 3$, was observed the increasing of pregenerative individuals and decreasing of generative individuals. Thus, pregenerative individuals in CP3 are $61 \%$, generative individuals $37 \%$ and post-generative individuals 2\% (Fig.5).
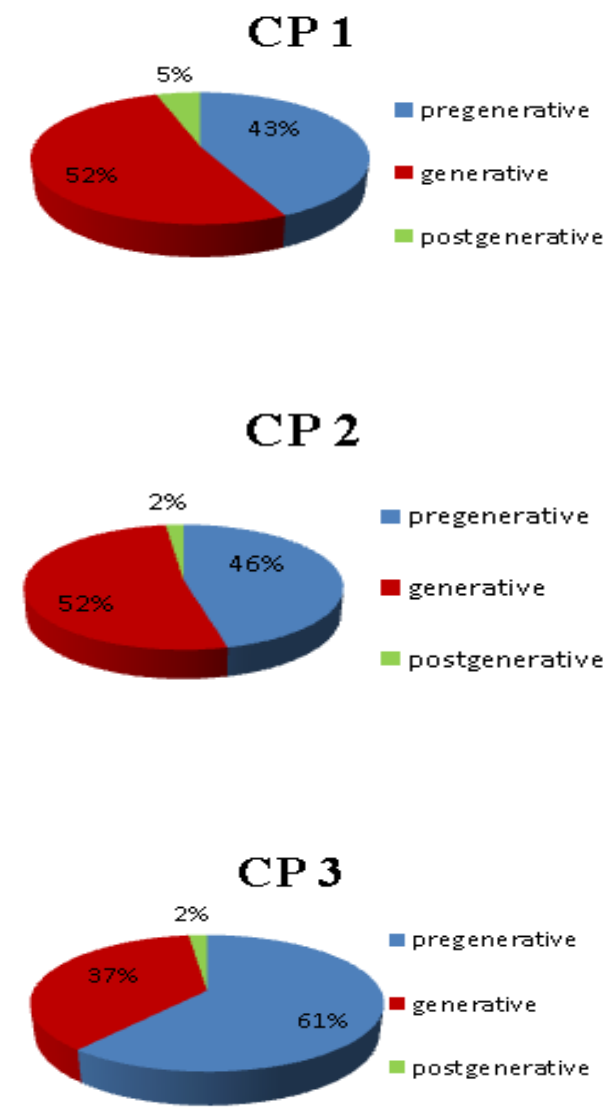

Figure 5. Ratio of pregenerative, vegetative and generative individuals in coenopopulations of $I$. reticulata $(\%)$.
As shown in the table 1, the highest number of individuals (n) and density (Xa) are CP1 and CP3 and the lowest in CP2. Density of individuals of pregenerative (Xpre) and generative $(\mathrm{Xg})$ in $1 \mathrm{~m} 2$ are identical to $\mathrm{CP} 1$ and CP3. Postgenerative (Xpost) individuals have a same density in $1 \mathrm{~m} 2$ in $\mathrm{CP} 2$ and $\mathrm{CP} 3$. Average density of generative individuals is the highest in CP2. The average density of postgenerative individuals is lowest at CP1. The recovery index (Ir) shows the highest mark in CP3. The aging index (Ia) is low in CP3. The value of the replacement (Irep) index is lowest in CP1, and the highest in CP3. According to the value of delta $(\Delta)$ and omega $(\omega)$, it is seen that each 3 coenopopulations are "young" type.

Morphometric characteristics. Measurements were made on individuals under 9 selected parameters. Morphograms were compiled for CP1, CP2, CP3 based on calculated values. In CP1 the length of leaf is $8.78 \pm$ 2.05 , the width of leaf $0.28 \pm 0.07$, the length of flower shoots $2.7 \pm 0.92$, the length of petal $3.08 \pm 0.33$, the width of petal $0.68 \pm 0.17$, the length of bulb $1.7 \pm 0.4$, the width of bulb $1.58 \pm 0.31$, the root length $6.2 \pm 0.75$, the number of roots $10 \pm 1.53$ (Fig. 6, A).

In CP2 the length of leaf is $10.8 \pm 1.69$, the width of leaf $0.48 \pm 0.17$, the length of flower shoot $3.06 \pm 1.01$, the length of petal $3.48 \pm 0.48$, the width of petal $0.98 \pm$ 0.15 , the length of bulb $2.12 \pm 0.29$, the width of bulb $1.85 \pm 0.27$, the root length $6.83 \pm 0.68$, the number of roots $10.66 \pm 1.79$ (Fig. 6, B). In CP3 the length of leaf is $10.24 \pm 1.72$, the width of leaf $0.38 \pm 0.13$, the length of flower shoot $3.06 \pm 1.01$, the length of petal $3.48 \pm 0.49$, the width of petal $0.98 \pm 0.15$, the length of bulb $2.12 \pm 0.29$, the width of bulb $1.85 \pm 0.27$, the root length $6.83 \pm 0.68$, the number of roots $10.67 \pm 1.79$ (Fig. 6, C). The difference in the number of rainy and frosty days, as well as in temperature degrees of Quba region for 2016-2017 has affected their morphometric features. As shown in Fig.6. the comparative analysis of the morphometric dimensions of I. reticulata in the investigated coenopopulations describe that the highest morphometric parameters for CP2 is the length and width of leaf, the length of flower shoot, the length of petal, the root length, the root number, for CP3 - the width of petal, the length and width of bulb. Morphological measurements in CP1 were relatively low.

The structure of morphological variability. Evaluation of variation coefficients of the selected parameters for analysis shows that in CP1 the least variation of petal length $(11 \%)$, root length $(12 \%)$, root number $(15 \%)$ and the highest is the length of flower shoot (34\%). 

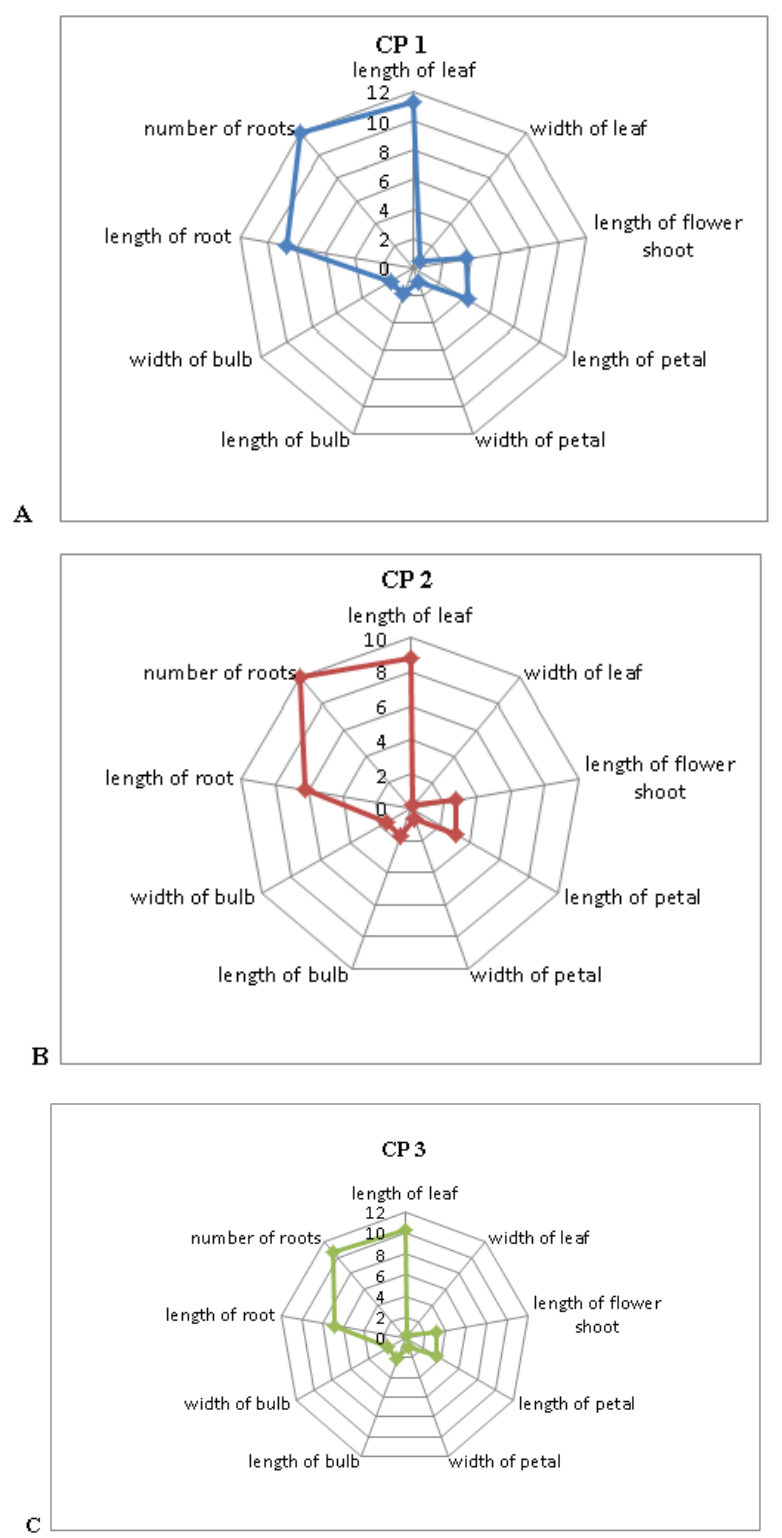

Figure 6. Morphograms of CP1 (A), CP2 (B) and CP3 (C) of I. reticulata.

The least varied in CP2 is root length (10\%), the strongest leaf width $(36 \%)$ and the length of flower shoot (33\%). In the CP3 as CP2 least varied is root length $(10 \%)$, the most powerful leaf width $(35 \%)$ and the length of flower shoot (35\%) (Table 2). In all three coenopopulations the least varied is the length of root (10-
$12 \%)$, the highest the length of flower shoot (33-35\%).

As shown in Table 2, the highest Ip value in CP1 is the length of flower shoot (0.62) and the lowest root length (0.28). In CP2 the highest values are the leaf width (0.72), the length of flower shoot (0.6) and the lowest value is the root length $(0.25)$. The highest value in CP3 is the leaf width (0.67), the length of flower shoot (0.6), and the lowest value is the root length $(0.25)$. According to the indication above it is seen that for 3 coenopopulations high plastic parameter to environmental change is length of flower shoot (0.6-0.62) and low plastic root length $(0.25-0.28)$. In addition to $\mathrm{CP} 2$ and $\mathrm{CP} 3$, the most powerful plastic is width of leaf (0.67-0.72).

Correlation analysis. Correlation analysis was performed to determine the relations between different part of plant. As a result it was established that: In CP1: the length of leaf $\sim$ the width of leaf $(r=0.63)$, the length of bulb $\sim$ the width of bulb $(r=0.41)$, the root length $\sim$ root number $(r=0.73)$, petals length $\sim$ petals width $(r=$ $-0.71)$, the length of leaf $\sim$ the length of petal $(r=0.38)$, the width of leaf $\sim$ the width of petal $(r=-0.49)$, the length of flower shoot $\sim$ the length of petal $(r=0.79)$, the length of flower shoot $\sim$ width of petal $(r=-0.64)$. In $\mathrm{CP} 2$ : the length of leaf $\sim$ the width of leaf $(\mathrm{r}=-0.77)$, the length of bulb $\sim$ the width of bulb $(r=0.14)$, the root length $\sim$ root number $(r=0.29)$, petals length $\sim$ petals width $(r=-0.22)$, the length of leaf $\sim$ the length of petal $(r=0.15)$, the width of leaf $\sim$ the width of petal $(r$ $=-0.41)$, the length of flower shoot $\sim$ the length of petal $(r=0.78)$, the length of flower shoot $\sim$ width of petal $(r$ $=-0.57)$. In CP3: the length of leaf $\sim$ the width of leaf $(\mathrm{r}=-0.92)$, the length of bulb $\sim$ the width of bulb $(\mathrm{r}=$ $0.14)$, the root length $\sim$ root number $(\mathrm{r}=0.22)$, petals length $\sim$ petals width $(r=-0.23)$, the length of leaf $\sim$ the length of petal $(r=0.29)$, the width of leaf $\sim$ the width of petal $(r=-0.53)$, the length of flower shoot $\sim$ the length of petal $(r=0.78)$, the length of flower shoot $\sim$ width of petal $(r=-0.57)$.

It was found that in CP1 strong correlation is observed between root length $\sim$ root number $(\mathrm{r}=0.73)$, length of flower shoot $\sim$ length of petal $(r=0.79)$. There is nega-

Table 1. Demographic parameters of coenopopulations of I. reticulata.

\begin{tabular}{llllccccccl}
\hline \hline No & \multicolumn{1}{c}{$\mathrm{n}$} & $\mathrm{X}_{\mathrm{a}}$ & $\mathrm{X}_{\text {pre }}$ & $\mathrm{X}_{\mathrm{g}}$ & $\mathrm{X}_{\text {post }}$ & $\mathrm{I}_{\mathrm{r}}$ & $\mathrm{I}_{\mathrm{a}}$ & $\mathrm{I}_{\text {rep }}$ & $\Delta$ & $\omega$ \\
\hline CP 1 & 136 & 17 & 34,5 & 4,62 & 0,25 & 0,82 & 0,051 & 0,74 & 0,33 & 0,58 \\
CP 2 & 48 & 6 & 7,25 & 8,87 & 0,87 & 0,88 & 0,021 & 0,85 & 0,28 & 0,56 \\
CP 3 & 447 & 55,87 & 34,5 & 4,62 & 0,87 & 1,682 & 0,016 & 1,64 & 0,291 & 0,446 \\
\hline
\end{tabular}


PLANT \& FUNGAL RESEARCH

Table 2. Variability and plasticity of the morphoparameters of individuals I. reticulata.

\begin{tabular}{lllccccc}
\hline \hline \multirow{2}{*}{ No } & Parameteres & \multicolumn{2}{c}{ CP 1 } & \multicolumn{2}{c}{ CP 2 } & \multicolumn{2}{c}{ CP 3 } \\
\cline { 3 - 8 } & $\begin{array}{c}(\mathrm{Cv}), \\
\%\end{array}$ & Ip & $\begin{array}{c}(\mathrm{Cv}), \\
\%\end{array}$ & Ip & \multicolumn{2}{c}{$\begin{array}{c}\text { (Cv), } \\
\%\end{array}$} & Ip \\
\hline 1 & Length of leaf & 23 & 0.49 & 16 & 0.39 & 17 & 0.39 \\
2 & Width of leaf & 27 & 0.5 & 36 & 0.72 & 35 & 0.67 \\
3 & Length of flower shoot & 34 & 0.62 & 33 & 0.6 & 35 & 0.6 \\
4 & Length of petal & 11 & 0.26 & 14 & 0.33 & 14 & 0.33 \\
5 & Width of petal & 25 & 0.5 & 15 & 0.33 & 15 & 0.33 \\
6 & Length of bulb & 24 & 0.5 & 14 & 0.31 & 14 & 0.31 \\
7 & Width of bulb & 19 & 0.45 & 15 & 0.37 & 15 & 0.38 \\
8 & Length of root & 12 & 0.28 & 10 & 0.25 & 10 & 0.25 \\
9 & Number of root & 15 & 0.42 & 17 & 0.38 & 17 & 0.38 \\
\hline
\end{tabular}

tive relation between length of petal $\sim$ width of petal, leaf width $\sim$ width of petal, length of flower shoot $\sim$ length of petal. The strong correlation in CP2 between the lengths of flower shoot $\sim$ length of petal, in other parameters a weak correlation. There is negative relation between length of leaf $\sim$ width of leaf, length of petal $\sim$ width of petal, width of leaf $\sim$ width of petal, length of flower shoot $\sim$ width of petal. In CP3 the strong correlation between the lengths of flower shoot $\sim$ length of petal. Negative correlation is length of leaf $\sim$ width of leaf, length of petal $\sim$ width of petal, width of leaf $\sim$ width of petal, length of flower shoot $\sim$ width of petal. The strong correlation between the parameters in all three coenopopulations was between the lengths of the flower shoot $\sim$ length of petal.

\section{CONCLUSION}

Recently it is observed that, the steady growth trend of anthropogenic and abnormal natural factors to the environment affect adversely, firstly to the endangered populations, especially vulnerable and rare plant species. Investigations the population biology of rare and endangered plant species makes it possible objectively to assess the state of their populations, which is very important for taking effective conservation measures [Rabotnov, 1975]. In the flora of Azerbaijan, among these plants, a separate place is occupied by species from the family Iridaceae Juss., which their protection is particularly important today. Previously, we have studied the ontogenetic features, the state of coenopopulations and the variability of the morphometric characteristics of rare species Ophrys caucasica Woronow ex Grossh., Galanthus caucasicus (Baker) A. Grossh., Platanthera chlorantha (Cust.) Reichenb. [Bayramova et al., 2018; Mursal, 2018; Mursal, Mehdiyeva, 2016]. The present work is a continuation of the study of rare species (in particular, I. reticulata) in this direction. In the period of the research, an assessment of the state of coenopopulations I. reticulata in various habitats in Quba region was made. The analysis of biometric parameters was conducted which allowed to identify structural features of plants, the nature of the variability of their parts and investigated the correlation relations between them. The study of the morphological features I. reticulata distributed in Quba region made it possible to reveal the ability of the coenopopulations of this species responding with the variability of the morphological features on ecological conditions during period of their vegetation.

\section{REFERENCES}

Alekseyeva N.B. (2008) Rod Iris L. (Iridaceae) v Rossii. Turczaninowia, 11(2): 5-68. (In Russian)

Azərbaycan Respublikasının Qırmızı kitabı. Nadir və nəsli kəsilməkdə olan bitki və göbələk növləri (2013) Ed.: Bağırov H.S., Oliyev C.Ә., 2-ci nəşr. Bakı: Qərb-Şərq, 676 pp. (In Azerbaijani)

Bayramova M.D., Mursal N., Mehdiyeva N.P. (2018) The state and ontogenetic structure of coenopopulations of rare species Galanthus caucasicus (Baker) A.Grossh. in Qusar district of Azerbaijan. Web of Scholar International Academy Journal, 2: 3-7.

Braun-Blanquet J., Pavillard I. (1925) Vocabulaire de sociologie végètale. 2e éd. Montpellier, $22 \mathrm{pp}$.

Әsədov K.S., Məmmədov F.M., Sadıxova S.Ә. (2008) Böyük Qafqazın şimal-şərq hissəsinin dendroflorası və meşələri. Bakı, 276 pp. (In Azerbaijani)

Flora Azerbaidjana (1952) Ed.: D.I.Sosnovski, I.I. Karyaqin. Baku: AN Azerb. SSR, 2: 214 p. (In Russian)

Harborne J.B., Williams C.A. (2000) The phytochemi- 
cal richness of the Iridaceae and its systematic significance. Annali Di Botanica, 58: 43-50.

Khapuqin A.A., Varqot E.V., Chuqunov Q.Q. (2015) Ob Iris aphylla L. (Iridaceae Juss.) - novom vide dlya territorii natsionalnoqo parka "Smolniy" Saransk-Smolniy. Nauchnie trudi nachionalnoqo parka "Smolniy" Saransk-Smolniy., 2:143-148. (In Russian)

Khomann E.E., Zayakin V.V., Mu-Za-Chin V.V., Semenishchenkov Yu. A., Nam I.Y. (2016) Soxranenie redkoqo v Bryanskoy oblasti vida Iris aphylla L. (Iridaceae) v kulture in vitro. Veschi Nachinalnay Akademii Navuk Belarusii, 1: 102-106. (In Russian)

Konspekt Flori Kavkaza. (2006) Ed.: A.L.Taxtadjan. Sankt Peterburq: SPBQU, 2: 467 pp. (In Russian)

Krick W., Marner F.J., Jaenicke L. (1983) Isolation and structure determination of the precursors of alphairone and gamma-irone and homologous compounds from Iris pallida and Iris florentina. Z Naturforsch C, 38: 179-184.

Mamaev S.A. (1972) Formi vnutrividovoy izmenchivosti drevesnix rasteniy. Moskva: Nauka, 283 pp. (In Russian)

Ministry of Ecology and Natural Resources of Azerbaijan Republic. http://eco.gov.az/az

Morita N., Shimokoriyama M., Shimizu M. (1972) Studies on medicinal resources XXXIII. The Components of rhizome of Iris tectorum (Iridaceae). Yakugaku Zasshi, 92 (8): 1052-1054.

Mu-Za-Chin V.V., Shukal V.V. (2016) Kharakteristika tsenopopulyatsiy Iris sibirica L. (Iridaceae Juss.) v poymakh rek v Bryankoy oblasti. Bulleten Bryanskoqo otdeleniya RBO, 2(8): 36-43 (In Russian)

Mursal N., Mehdiyeva N.P. (2016) Ontogenetic structure and phytocenotic characteristic of coenopopulations of rare species Platanthera chlorantha (Cust.) Reichenb. in Quba district of Azerbaijan. Proc. Biol. Med. Sci. of ANAS, 71(3): 39-44.

Mursal N. (2018) Ontogenetic structure and variability of morphometric parameters of rare species of $\mathrm{Oph}$ rys caucasica Woronow ex Grossh. Conference of Young Scientists and Students, Innovations in Biology and Agriculture to Solve Global Challenges, Azerbaijan, Baku, 31/10, pp.122.

Odum Y. (1952) Ekologiya. Perevod s anqliyskoqo yazika. Moskva: Mir, 2: 376 pp. (In Russian)

Polevaya geobotanika (1964) Ed.: E.M. Lavrenko, A.A. Korchagina. Moskva- Leninqrad: Nauka, 3: 532 pp. (In Russian)

Rabotnov T.A. (1950) Voprosii izucheniya sostava populyatsiy dlya tseley phytotsenologiya. Problemi botaniki, 1: 465-483. (In Russian)

Rabotnov T.A. (1975) Izucheniye tsenoticheskix populyatsiy v chelyax viyasneniya strateqii jizni vidov rasteniy. Bul. MOIP. Otd. Biol., 80(2): 5-17 (In Russian)

Rastitelniye resursi Rossii i sopredelnix qosudarstv. Chevetkovie rasteniya, ix khimicheskiy sostav, izpolzovanie. Semeystva Butomaceae-Typhaceae (1994) Ed.: P.D.Sokolov. Sankt-Peterburq: Nauka, 8: 271 pp. (In Russian)

Rastitelniye resursi Rossii. Dikorastushie chevetkovie rasteniya, ix komponentniy sostav i bioloqicheskaya aktivnost. Semeystva Butomaceae-Typhaceae (2014) Ed.: A.L.Budantsev. Sankt-Peterburq-Moskva: Tovarishestvo nauchnix izdaniy KMK, 6: 392 pp. (In Russian)

Rostova N.S. (2002) Korrelyatsiy: struktura i izmenchivost. Sankt-Peterburq: Izd. S.-Peterburqskava Universiteta, 308 pp. (In Russian)

Seki K., Tomihari T., Haga K. (1994) Iristectorene B, a monocyclic triterpene ester from Iris tectorum. Phytochemistry, 36(2): 433-438.

Semenishenkov Y.A. (2010) Monitorinq redkix vidov rasteniy $\mathrm{v}$ soobshestvax mezokserotermnix dubrav predpolessix landshaftov $\mathrm{v}$ Bryanskoy oblasti. In: Y.A. Semenishenkov, V.V. Mu-Za-Chin. Flora i rastitelnost Chentralnoqo Chernozemya. Materialiy nauchniy konfrensiya, Kursk, 25/03, pp. 120-122 (In Russian)

Semenishenkov Y.A. (2014-2015) Soobshestva kseromezophytnix shirokolistvennix lesov u qranichi Bryanskoy i Orlovskoy oblastey i ix prirodooxrannoe znacenie. In: Y.A. Semenishenkov, D.A. Kobozev, V.V. Mu-Za-Chin. Ejeqodnix NII fund. i prikl. issled., pp. 54-60 (In Russian)

Senchuqova M.A., Chuqunov Q.Q., Khapuqin A.A. (2017) Populyatsionniye issledovaniya Iris aphylla (Iridaceae), Cephalanthera rubra (Orchidaceae) i Lilium martagon (Liliaceae) na vostoke respubliki Mordoviya v 2016 qodu. Tr. Mordov. Qos. pririd. zapoved. im. P.Q. Smidovicha, 18: 206-214. (In Russian)

Sericova V.I., Lepeshkina L.A., Voronin A.A., Kuznetsov B.I. (2013) Ontogenez kasatika nizkoqo (Iris pumila L.) ontogeneticheskiy atlas rasteniy. Yoshkar-Ola: Nauchnoe izdaniye, 7: 364 pp.

(In Russian)

Shmaraeva A.N., Shishlova Zh.N., Fedyaeva V.V. (2014) Kasatik nenastoyashiy (Iris notha Bieb.) v 
Azovskom rayone Rostovskoy oblasti. Electronnoe periodicheskoe izdaniye YFU, Zhivie biokosnie sistemi, 8: 97-108 (In Russian)

The Plant list: http://www.theplantlist.org/tp11.1/record/ kew-2748734

Uranov A.A. (1975) Vozrastnoy spektr fitopopulyatsiy kak funktsiya vremeni energeticheskix volnovix protchessov. Biol. Nauki, 2: 7-34 (In Russian)

Uranov A.A. (1977) Voprosii izucheniya strukturi phytochenozov i vidoviz tsenopopulyatsiy. Tsenopopulyatsiy rasteniy. Razvitie i vzaimootnosheniya. Moskva: Nauka, pp. 8-20. (In Russian)

Williams Ch.A., Harborne J.B., Colasanthe M. (1997) Flavonoid and xanthone patterns in bearded Iris species and the pathway of chemical evolution in the genus. Biochem Syst Ecol, 25(4): 309-325.

Wu Y.X., Xu L.X. (1992) Analysis of isoflavones in Belamcanda chinensis and Iris tectorum by square wave voltammetry. Acta Pharm Sin B, 27: 64-68.

Zauqolnova L.B., Zhukova L.A. Komarov A.S., Smirnova O.V. (1988) Tsenopopulyatsii rasteniy (ocherki populyatsionnoy biologii). Moskva: Nauka, 184 pp. (In Russian)

Zhivotovski L.A. (2001) Ontogeneticheski sostoyaniya, effektivnost i klassifikasiya populyachiy rasteniy. Ekologiya, 1: 3-7 (In Russian)

Zlobin Y.A. (1989) Prinsipi i metodi izucheniya tsenoticheskix populyatsiy rasteniy. Kazan: KQU, 146 pp. (In Russian)

Zlobin Y.A., Sklyar V.Q., Klimenko A.A. (2013) Populyatsiy redkix vidov rasteniy: teoreticheskiye osnovi i metodika izucheniya. Sumi, Universitetskaya kniqa. 439 pp. (In Russian)

\section{Iris reticulata $\mathrm{M}$. Bieb. növünün}

\section{senopopulyasiyalarinin ontogenetik strukturu vo morfoparameterlərinin dəyişkənliyi}

\section{Nigar Mürsəl}

Naibə P. Mehdiyeva

AMEA Botanika Institutu, Badamdar şossesi 40, Bakl, AZ1004, Azarbaycan

Məqalədə Iris reticulata M. Bieb. nadir növünün Quba rayonunda(Azərbaycan)yayılan senopopulyasiyalarının (SP) təsviri, ontogenetik və demoqrafik strukturu verilmişdir. Məlum olmuşdur ki, bütün senopopulyasiyalar soltərəfli spektrə malikdir, SP1 və SP2-də ən yüksək faizi generativ fərdlər, SP3-də isə pregenerativ fərdlər təşkil edir. Delta $(\Delta)$ və omega $(\omega)$ qiymətləndirilməsi göstərmişdir ki, hər 3 senopopulyasiya cavan tiplidir. Senopopulyasiyalardakı fərdlərin morfometrik analizi, morfomaparameterlər arasında korrelyasiya analizi aparılmış, dəyişkənlik və plastiklik müəyən edilmiş, onlara iqlim amillərinin təsiri araşdırılmışdır. İki illik iqlim göstəriciləri - temperatur, şaxtalı və yağışlı günlərin sayında fərqin olması onların morfometrik gostəricilərində, dəyişkənlik və plastiklik əlamətlərində özünü büruzə vermişdir. Tədqiqatlar əsasında müəyyən olmuşdur ki, ən yüksək qiymət SP2-də yarpaq uzunluğu, yarpaq eni, çiçək saplağı uzunluğu, ləçək uzunluğu, kök uzunluğu, kök sayı əlamətləri, SP3-də - ləçək eni, soğanaq uzunluğu və soğanaq eni əlamətləri göstərir. On aşağ1 morfoloji ölçülər SP1-də müşahidə olunub. Variasiya koeffsientlərinin qiymətləndirilməsi göstərmişdir ki, hər üç senopopulyasiyada ən az variasiya edən kök uzunluğu (10-12 \%), ən yüksək variasiya edən isə çiçək saplağının uzunluğu (33-35\%) olmuşdur. Hər üç senopopulyasiyada ən plastik əlamət çiçək saplağının uzunluğu (0.6-0.62), ən az plastik əlamət isə kök uzunluğu (0.25-0.28) olmuşdur. SP2 və SP3-də əlavə olaraq ən güclü plastik əlamət yarpaq eni (0.67-0.72) olmuşdur. Korrelyasiya analizinin nəticəsinə əsasən hər üç senopopulyasiyadakı parameterlər arasında güclü korrelyasiya əlaqəsi çiçək saplağının uzunluğu $\sim$ ləçək uzunluğu arasında olmuşdur. Tədqiqatlar göstərmişdir ki, həmin ərazilərdə I. reticulata bitkisinin sayının azalmasina antropogen və təbii amillər təsir göstərir. Açar sözlor: ontogenetik struktur, dəyişkənlik, plastiklik, korrelyasiya, iqlim amili

\section{Онтогенетическая структура ценопопуляций и изменчивость морфопараметров Iris reticulata M. Bieb.}

\section{Нигяр Мурсал \\ Наиба П. Мехтиева \\ Институт Ботаники НАНА, Бадамдар 40, Баку, AZ1004, Азербайджан}

В статье приводятся описание, онтогенетическая и демографическая структура трех ценопопуляций (ЦП) редкого вида Iris reticulata M. Bieb., pacпространенного в Губинском районе Азербайджана. Выявлено, что все ценопопуляции характеризуются левосторонним онтогенетическим типом спектра, самый высокий процент в ЦП1 и ЦП2-составляют генеративные особи, в ЦП 3 - прегенеративные. Согласно значениям индексов возрастности $(\Delta)$ и эффективности $(\omega)$, все 3 ценопопуляции можно от- 
нести к молодым типам. Проведен морфометрический анализ особей исследуемых ценопопуляций, а также корреляционный анализ между морфопараметрами, установлено влияние климатических факторов на их изменчивость и пластичность. Различия в количестве дождливых и морозных дней, а также в показателях температуры воздуха в течение 2-х летнего периода отразились на морфометрических параметрах и показателях изменчивости и пластичности. Наиболее значимыми морфопараметрами в ЦП2 являются длина листа, ширина листа, длина цветочного побега, длина лепестка, длина корня, количество корней, а в ЦПЗ - ширина лепестка, длина луковицы, ширина луковицы. Самые низкие морфопоказатели отмечены в ЦП1. Определение коэффициентов вариации показало, что во всех трех ЦП наименее изменчивой оказалась длина корня (10-
$12 \%)$, а наиболее изменчивой - длина цветоносного побега (33-35\%). Во всех ЦП самым пластичным морфопараметром является длина цветоносного побега (0.6-0.62), кроме того, в ЦП2 и ЦП3 - ширина листа (0.67-0.72) тоже явилась наиболее показательным пластичным признаком. Наименее пластичным параметром для всех 3-х ЦП явилась длина корня (0.25-0.28). В результате проведенного корреляционного анализа установлено, что во всех трех ЦП наибольшая корреляция наблюдалась между длиной цветоносного побега и длиной луковицы. Исследования показали, что сокращение числа особей $I$. reticulata в районе исследования вызывают антропогенные и природные факторы.

Ключевые слова: онтогенетическая структура, изменчивость, пластичность, корреляция, климатический фактор 